\title{
The art of non-verbal communication in perlocutionary giftedness
}

\author{
Adam Świątek \\ State University of Applied Sciences in Konin, Poland
}

\begin{abstract}
Language aptitude and perlocutionary acts and effects have been subjects of extensive research since their true beginnings in the 1950's and 1960's, respectively. On the one hand, Carroll and Sapon (1959), Pimsleur (1966), or Biedroń (2012) aimed at revealing the factors responsible for a learner's sixth sense for languages. On the other hand, almost simultaneously, Austin (1962) introduced the tripartite division of a speech act, with locutions, illocutions, and perlocutions as the integral components, later developed by Searle (1969), who shed new light on the Speech Act Theory (SAT). At that time, however, the role of the perlocutionary component was significantly diminished, since the primary goal of pragmatics was to investigate the speaker's intentions. Gradually, the role of perlocutionary acts and effects changed and more attention was drawn to the perlocutionary aspect. In 1979, Cohen, Davis and Gaines highlighted the fact that perlocutionary acts have perlocutionary goals, which might be observed by the subsequent effects utterance have on the listener. In 2013, Post offered a new insight into the SAT and suggested that the role of perlocution ought not to be diminished, but enhanced and intensified. In 2015, Swiątek suggested a contrasting approach to both concepts and combined them to investigate the role of individual differences responsible for one's verbal perlocutionary giftedness. The research revealed that the aspects like verbal aptitude, anxiety, willingness to communicate, or personality type had considerable impact on perlocutionary skills and the desired perlocutionary effects. Świątek's approach shed new light on the research on pragmatic aspects of glottodidactics and opened a new chapter in that field of science. The aim of the presentation is to concentrate on yet another fundamental factor of perlocutionary giftedness, i.e. non-verbal aspects in its manifestation. The research, based on experiential and comparative methods as well as individual case analysis, aimed at revealing a strong link between verbal perlocutionary giftedness and the accompanying non-verbal aspects of communication, such as kinesics, proxemics, vocalics, or posture, which affect the listener's decisions, who then complies with the speaker's will.
\end{abstract}

Keywords: aptitude, communication, individual differences, perlocution

\section{Introduction}

In 1962, Austin introduced the Speech Act Theory (SAT), which contained the tripartite division of a speech act consisting of locutionary, illocutionary and perlocutionary components, each of them comprising an integral and indispensable part of an individual utterance. Essential as it was, SAT allowed to understand how utterances functioned from the pragmatic point of 
view. However, the early version of the SAT did not aim at investigating the perlocutionary component and therefore effects utterances have on the recipient. It focused on the speaker's intentions and gave the illocutionary component primary importance in an act of communication. In 1979, Gaines, Cohen and Davis highlighted the fact that the perlocutionary component ought to be given more attention, since studying the effects utterances have on the addressee might contribute to a tremendous breakthrough in terms of understanding how the speaker's words impact other language users and therefore their verbal and non-verbal reactions. The above-mentioned stance on the position of perlocutionary acts and effects in the SAT and pragmatics itself facilitated the revival of interest in the phenomenon of perlocution and led to a new wave of research regarding this component of the entire theory. Over the years, the position of perlocutionary speech acts has been even intensified by numerous empirical studies conducted by Osika (2008), Plisiecka-Witczak (2013), Post (2013), or Huang (2014). In 2016, Swiątek decided to develop the research on the perlocutionary component of the SAT even further and introduced the phenomenon of perlocutionary aptitude (also referred to as giftedness) defined as a complex set of individual features which might contribute to one's increased communicative effectiveness and therefore success over particular language users in an act of verbal communication. Furthermore, when considering the most recent perspective regarding the phenomenon of perlocution, it ought to be taken into consideration not only when discussing the linguistic viewpoint but also changing trends and requirements in contemporary language education and instruction, which, according to the latest curriculum, pays more attention to effective and therefore successful speaking and communication. Complex as it seems to be, perlocution is a significant and indispensable part of this process. In consequence, with more attention given to verbal communication and effective language use, teachers and instructors can notice that there are language users who seem to be more flexible when changing their roles from the speaker's to the listener's. There also seem to be speakers who easily intimidate other language users and make them accept their viewpoints without any significant negotiation of meaning or conditions by making use of multiple non-verbal means of communication and therefore increasing their communicative efficiency.

The present article concentrates on an array of non-verbal aspects of communication that strengthen the effectiveness of individual manifestation of verbal perlocutionary giftedness. Therefore, Świątek's main goal is to pinpoint the most essential and, at the same time, relevant components of non-verbal communication that appear when exchanging information between language users, with their impact on the speaker's final, communicative success or failure, or even the listener's abandonment and compliant tendencies in conversational contexts. Thus, the article consists of two interrelated parts; the initial section of the paper focuses on the theoretical support for the phenomenon of perlocutionary aptitude, by means of the historical background of perlocution, its rejection, revival, and the latest, innovative research on the phenomenon with the verbal perlocutionary aptitude as the turning point in the study of this contemporary approach towards the presented concept. The second part of the article is entirely devoted to the practical research conducted by Swiątek, aimed at determining the extent to which perlocutionarily gifted language users adopt non-verbal aspects of communication, such as proxemics, kinesics, oculesics, or chronemics, in order to force the speaker's target issue, i.e. 
manipulate, confuse and make the listener feel uncomfortable so that one decides to abandon the target act of communication.

\section{Perlocutionary Speech Act Theory vs. language aptitude}

Language aptitude and the Perlocutionary Speech Act Theory (PSAT) had long been treated as separate concepts. Different as they seem to be, there are common points between both concepts, especially in how they correlate and affect language users; in other words, bothof them bear a considerable degree of resemblance.

To start with, language aptitude has been modelled as an inborn, 'sixth sense' for language learning, which usually boosts one's language comprehension. Furthermore, pioneering the concept, Carroll (1962) stressed the fact that aptitude ought to be treated as independent of intelligence and enhanced by communicative opportunities. In 1997, Ellis described aptitude as a process that enables language users to proceed and absorb language data more efficiently. Brown (2000) described it as a particular piece of 'equipment' one uses to absorb language knowledge, whereas Biedron (2011) maintains that aptitude is one's readiness for language absorption with a guaranteed rate of achievement. Finally, a thought-provoking description came from Safar and Kormos (2008) who highlighted the fact that aptitude resembles language progress independent of the wishes of a language user. Therefore, whether one works with the language more or less efficiently, progress and development are unavoidable. However, in order to find similarities between the PSAT and language aptitude, a deeper insight into the concept is necessary.

Dornyei and Skehan (2003) implied that aptitude is the distinctive concept that allows to distinguish particular language users from among the other language community members and determines individual differences between them. Snow (as cited in DeKeyser 2007) maintains that aptitude is the notion that enables multitasking and dealing with particular challenges in numerous ways, usually applying different approaches. What is more, aptitude determines individual differences between language users.

When it comes to individual differences among speakers, the phenomenon of perlocution seems to be another factor that brings and determines diversity in the verbal effectiveness and individual viewpoint manifestation. It is also related to language aptitude and verbal skills since skilful language users can, even subconsciously, make use of their individual language resources to apply perlocutionary skills for their own purposes.

The role of perlocutionary skills had long been diminished and reduced to an absolute minimum. In 1962 Austin defined perlocutionary acts as a unique instrument that allows a language user to influence and evoke certain changes in the feelings or behaviour of the listener. Furthermore, the effects do not have to be single consequences; it is possible to evoke complex stretches of them, sometimes unwanted, or even unintentional. Austin's view was supported by numerous researchers, such as Cohen (1979), Davis (1979), or Gaines (1979), who even suggested a taxonomy of perlocutionary effects (voluntary and involuntary; epistemic and motivational; practical) as well as two genera gathering all the categories of perlocutionary effects, subdivided into perfected and incipient. Osika (2001, 2008) and Cap (2010) added that 
the effects one intends to produce may be conscious and intentional, which implied that the effects might depend on the wishes of the speaker. What is even more, perlocutionary effects are simply the manifestation of understanding of particular utterances. Searle and Vanderveken's (1985) description maintains that perlocutionary effects are the essence of perlocutionary acts. Zdunkiewicz (1993) added that perlocutionary effects are simply the 'sideeffects' of perlocutionary acts. Finally, the most recent description came from Huang (2014) who pinpointed that perlocutionary acts and effects are the essence of speaking a language and executing procedures. Huang (2014) also claimed that they can be used to manipulate or direct other language users what to do in particular situations, or even produce some chain effects. However, some of the effects cannot be controlled. Huang also stressed the fact that speaking a language seems to be a matter of following some conventions and general rules, while producing perlocutionary effects is beyond one's expectations and wishes since they cannot be predicted.

Speaking and perlocutionary acts and effects are inseparable elements of communication and language use. Speaking cannot exist without perlocutionary acts and effects, as both notions seem to be highly correlated and interdependent. However, the notion of perlocutionary acts and effects has not always been given a priority.

\section{Rejection to investigate perlocution}

Austin's (1962) theory suggested a trichotomy of speech acts, with locutionary, illocutionary, and perlocutionary acts as their core components. However, researching perlocutionary acts and effects was immediately rejected since locutionary acts and perlocutionary acts were situated on different logical levels. Moreover, pragmatics did not aim at investigating the effects of communication, but the intentions of the speaker. In other words, the role of the hearer was significantly diminished (Post 2001). The same approach towards perlocutionary acts and effects was adopted by Searle $(1962,1968,1969)$, who systematised Austin's theory and still maintained the primary function of illocutionary acts. Searle $(1975,1976)$ also rejected studying locutionary acts since the relation between locution and illocution was, according to him, too complicated and unclear, and offered a comprehensive classification of illocutionary acts, later supported by, for instance, Kalisz (1993) and Vanderveken (2002). However, Plisiecka-Witczak (2013) pinpoints that Searle did not really reject locutionary acts, but redistributed their role.

Growing concerns over the fact that deep structures of the main clauses contained performative verbs and exerted a certain degree of impact on the hearer, led to an assumption that the perlocutionary aspect might be an important aspect of communication (Ross 1970; Sadock 1974). Unfortunately, even that kind of assumption still maintained the illocutionaryoriented approach towards the SAT and placed illocutionary acts in the centre of attention. In consequence, Campbell (1973) treated perlocution critically and negated its importance for the study of speech acts. Levinson (1980) claimed that perlocution constituted a marginal component of communication, which ought not to be taken into consideration and therefore analysed. Leech (1983) stressed the fact that perlocution was too wide a phenomenon, and it would be difficult to investigate it as no frames for the study of perlocution had ever been suggested or developed. Even in recent years, Marcu (2000) referred to the view presented by Campbell in 1973. However, already in the late 70's, the view on speech acts and, especially, 
perlocutionary acts and effects began to change and some researchers suggested that the perlocutionary component ought to be given more attention, regardless of what the other researchers claimed or highlighted on a simultaneous basis.

\section{The importance of perlocution}

In 1979, Gaines, Davis, and Cohen appealed for the recognition of perlocutionary acts and effects and suggested a perlocutionary-oriented approach towards the study of speech acts and their subsequent effects. They reminded the academic community of the importance of the effects utterances have on the hearers as well as the impact of communicative situations on language users. They also claimed that illocution was an inseparable element of perlocution, and both were instrumentally related. Furthermore, uttering words always brings a perlocutionary goal, or simply intentions, and illocution seems to be the tool for executing particular perlocutionary goals. Davis (1979) also mentioned that illocutions have perlocutionary goals related on a conventional basis, i.e. generic perlocutionary purposes. Cohen (1979) introduced the notion of associated perlocutions, which meant particular effects assigned to specific illocutions. Finally, he added that every illocutionary act may generate numerous effects simultaneously, thus revealing the unconventional nature of perlocution. As a result, in the late 1970's the interest in perlocutionary acts and effects was revived.

A real breakthrough, however, came in the late 1990's when Post (1999a, 1999b, 1999c, 2001, 2013) offered a radical proposal for the study of the phenomenon of Perlocutionary Speech Act Theory. Post situated speech acts on the same level with perlocutionary acts and declared that they ought to be equated. Post (2013) abandoned the traditional relation of speech acts, antecedent-consequent, and introduced the idea of the whole-part relation. Furthermore, Post (2013) pinpointed that perlocutionary acts could be investigated in an empirical way by analysing the addressee's verbal and non-verbal reactions to the speaker's utterances. In other words, both perspectives, i.e. the hearer's and the listener's ought to be considered in order to get a clear picture of what the phenomenon means. Post (2011) also supported Krzeszowski's (1997) earlier view on the fact that perlocutionary acts could be axiologically measured and seem to be bearers of axiological charge. Furthermore, Post (1999b) introduced a taxonomy of perlocutionary expressions and attributed perlocutionary effects to the so-called perlocutionary forces. Finally, in 2001, Post suggested the concepts of intended and unintended perlocutionary acts as well as provided researchers with another, third type of perlocutionary acts, i.e. default perlocutionary acts.

The 1970's revival of interest in as well as Post's enormous contribution to the development of perlocutionary acts and effects led to particular conclusions and therefore advancements that seem to have brought a contemporary wave of interest and innovative research on the concept.

\section{The emergence of verbal perlocutionary aptitude}

In 2015, perlocutionary acts and effects began to be researched from a totally innovative point of view, on the verge of pragmatics and glottodidactics. The research concentrated on one's 
individual skills necessary to manipulate and verbalise one's resources effectively in order to make the listener accept the presented, speaker's viewpoint, or simply give up a conversation and adopt the speaker's will. In other words, the research aimed at determining the role of individual differences, such as language anxiety, willingness to communicate, verbal aptitude, personality type, cognitive style, etc., to perform perlocutionary acts and elicit the target effects. Additionally, the research aimed at determining the profile of a verbally gifted language user in terms of eliciting perlocutionary effects.

As a result, the conducted set of experiments allowed to establish that perlocutionarily gifted language users do not feel anxious about speaking in any communicative situation, seem to be willing to communicate in every situation and tend to be grammatically and lexically sensitive. Furthermore, they properly adjust their language resources to manipulate and force listeners to accept their viewpoints, possess a high level of verbal aptitude and seem to be language-motivated and oriented. ${ }^{1}$ The research brought numerous possibilities in the field of perlocutionary acts and effects as well as resulted in the introduction of the concept of perlocutionary aptitude in 2016 by Świątek.

The empirical investigation regarding the newly-introduced concept was then continued in order to develop its major assumptions, since numerous notions seemed to exert various degrees of influence on the investigated phenomenon, concentrating on the roles of non-verbal aspects of communication, axiology, and multiple intelligences in verbal perlocutionary giftedness. However, priority was given to the initial one, i.e. non-verbal means of communication.

\section{The research}

\subsection{Aims}

The study outlined in the presented paper aimed at defining the scope of non-verbal aspects of communication used by perlocutionarily gifted language users in order to support and increase the effectiveness and efficiency of their verbal communication. In other words, the research aimed at revealing the extent to which perlocutionarily gifted language users apply such elements as proxemics, oculesics, kinesics, posture, chronemics, vocalics, and sound symbols in order to dominate the target conversation and make the other participant feel uncomfortable and accept the speaker's viewpoint.

\subsection{Methodology}

In order to achieve the established goal, the research was entirely based on the qualitative approach. Therefore, for the purpose of the study, the following methods were made use of:

1 A full description of a perlocutionarily gifted language user is available in Świątek, A. 2016. The role of individual differences in the verbal aptitude of advanced learners of English to perform perlocutionary acts. Wrocław: Wydawnictwo Wyższej Szkoły Filologicznej we Wrocławiu. 
- the experiential method,

- the comparative method,

- the individual case analysis method.

The choice of methods was mainly dictated by the specific nature of the presented research. According to Pieter (1967), the experiential method allows to deal with individual participants of the target research and observe language users in a specific environment, for instance, when dealing with a whole-body experience, like investigating non-verbal aspects of communication. In other words, it is the method that allows to investigate perlocutionary skills when playing with a language in a live, face-to-face act of communication. When it comes to the comparative method, Williams (2007) claims that this approach allows to contrast individually and collectively-approached members of the target research. It also enables the researcher to identify the aspects responsible for one's success or failure in the proper experiment. This method is closely related to the individual case analysis method which, according to Hajduk (2001) and Williams (2007), is an essential part of every scientific experiment since it enables researchers to compare individual participants of the study in order to find the extent of individualism made use of in the research. It also allows to find the distinctive features of the participants of the study and come to innovative conclusions.

\subsection{Participants}

As far as the participants are concerned, 38 subjects took part in the study All of them were advanced learners of English representing the $3^{\text {rd }}$ year of the Faculty of English Philology. The choice of the participants stems mainly from the fact that investigating verbal perlocutionary giftedness requires language users to implement multiple solutions and approaches when dealing with the target task and aiming at the final success. It is also worth mentioning that the study was almost entirely balanced between males and females, as there were 20 female and 18 male participants. Therefore, the rate of participants, based on a percentage share, was 53:47 for the female testees.

\subsection{Procedure}

For the purpose of this study, the author conducted a quantitative and qualitative analysis of the collected data. As a result, the study was divided into three separate stages, each of them having distinct goals and points to be put into practice. The initial stage focused on the investigation of individual differences of the participants in order to select perlocutionarily gifted language users, possessing more-than-average language skills and tendencies in terms of such elements as individual verbal aptitude, lexical and grammatical sensitivity, personality and cognitive style agreement, motivation to succeed, willingness to communicate, language orientation, risk-taking, anxiety, and, finally, the most important of all, perlocutionary skills from both the hearer's and the speaker's perspectives, together with the manipulation of felicity conditions. The participants were also asked to deal with a task on the selection of proper illocutions to realise particular perlocutionary acts. This stage was entirely based on an array of 
professional questionnaires analysed in terms of the detailed scores (accurate numbers of points) achieved by the subjects. However, as far as the illocutionary questionnaire is concerned, the author analysed the subjects' answers in terms of the ability to select proper illocutions and therefore realise every single perlocution designed for the purpose of this study. Since each of the provided illocutions in particular questions contained different lexical and grammatical components as well as implied a completely different purpose, the subjects were not only required to reveal a particular level of lexical and grammatical knowledge but also pragmatic awareness necessary to maintain the illocutionary-perlocutionary agreement. Finally, when it comes to the perlocutionary questionnaires, the author analysed the subjects' answers in terms of the lexis, grammar, coherence, cohesion, or expressive devices that they had applied in order to break felicity conditions, elicit the intended perlocutionary effects and succeed in an act of communication. Therefore, the initial stage revealed that some of the participants, despite being advanced language learners, did not present the skills that would allow them to deal with the task designed for the final stage. This was mainly connected with the fact that some of the subjects did not provide answers regarding the target illocutions and left them incomplete. In other words, they found it too challenging to complete the task, while their knowledge of language components and linguistic concepts turned out to be insufficient. As a result, the second stage allowed the author of the research to reject 14 subjects (first-stage scores rated as low or average), who were therefore not promoted to the last, third stage. As far as the final stage is concerned, the remaining 24 subjects were asked to deal with a communicative situation aimed at reaching a particular set of goals. The subjects were asked to deal with a real-life situation and negotiate an array of points. The main goal of the participants was to behave naturally and try to do as much as possible to convince and make the listener adopt their viewpoints and solutions. Concomitantly, the researcher recorded videos ${ }^{2}$ in order to analyse the situations presented by the participants. The videos aimed at reaching the main goal of the entire experiment, i.e. determine the scope to which perlocutionarily gifted language users apply non-verbal aspects of communication, such as proxemics, haptics, oculesics, etc., in order to support their acts of communication, look more convincing, overwhelm the listener, and make one adopt their viewpoints, even though the listeners did not intend to do so. However, in order to ensure reliability of the study, the final stage was also divided into two parts. In the initial one, the testees were asked to work in pairs and speak on a given topic to elicit the desired effects, whereas in the final one, they were asked to take part in a group discussion and talk about, nowadays regarded as sensitive topics, religion and politics. The choice of topics was also dictated by the fact that the sensitive approach easily provokes emotions and emotional instability. Therefore, students show much more willingness to defend their viewpoints and beliefs, which, in turn, elicits different behavioural aspects and tendencies. In consequence, the author conducted a thorough analysis of the recorded videos in order to reach numerous conclusions related to the non-verbal aspects that were most frequently applied by the participants of this study. In other words, when analysing non-verbal means of communication, video recordings allow researchers to observe how particular participants react and behave in

2 The video materials were recorded in accordance with the existing legal regulations and the consent given by the participants of the study. 
certain situations as well as what means of communication they make use of most frequently when attempting to defend their viewpoints in the case of a sudden influx of information from another language user. This also allows to observe what situations make them feel uncomfortable and how they tend to cope with communicative obstacles. Therefore, it is the qualitative analysis of video recordings that brings the most reliable conclusions when approaching this kind of research topic.

Altogether, the author managed to analyse the extent to which perlocutionarily gifted language users consciously apply various non-verbal means of communication in order to succeed in verbal interaction and therefore make the listener accept their viewpoint.

\section{Results and discussion}

Complex as the research was, investigating non-verbal communication brought numerous, valuable conclusions for the further study of perlocutionarily gifted language users. The research, as already mentioned in the paper, concentrated on the following aspects of nonverbal communication:

- proxemics (affecting the listener's personal space in terms of the distance between the speakers);

- oculesics (maintaining constant eye-contact with the listener and signalling unsatisfactory answers, disapproval, etc.);

- kinesics (using a variety of body language movements, such as shrugging shoulders, drumming fingers, scratching neck or head, using gestures and facial expressions, etc.);

- posture (maintaining the straight position of the body, i.e. no slouching, bending or applying nervous movements);

- chronemics (providing immediate answers and sustaining fluent exchange of information - no waiting or pausing);

- vocalics (applying varied intonation, pace and timbre when signalling emotions and various forms of behaviour);

- $\quad$ sound symbols (using no gap-fillers in order to sustain interaction, such as grunting, mumbling, etc.).

The results show that non-verbal aspects of communication seem to be an extensive part of human interaction and exert a great degree of influence on the other members of communicative acts if properly used. Moreover, they were especially applied by those testees who achieved higher scores in particular tests and questionnaires, i.e. on the first stage. That is why, for the purpose of this study, the author analysed the recorded videos carefully and collected data regarding various forms of behaviour applied by the subjects in particular moments of their conversations. This also allowed the researcher to enumerate the dominant features and, in the case of oculesics, calculate how much time a certain feature had been applied for.

As far as proxemics is concerned, the research showed that affecting the individual, personal space of non-dominating students allowed the dominating ones to be clearly in a superior position and force the listeners/receivers to accept even unwanted or undesired 
viewpoints and solutions. Furthermore, the experiments revealed that the dominating students were more likely to make other people feel uncomfortable, usually by getting closer to them, but rather on a subconscious basis. However, when affecting one's personal space, no haptics was made use of in order to support or strengthen their impact on the receivers. Proxemics seemed to be an invaluable part of the communication of dominating students, and it seemed to be extensively used by them in a variety of ways, such as to distract or disorientate other members of the research and place themselves in the leading positions. It is also worth mentioning that limiting the listener's personal space allowed the conversational partner to control the course of action when exchanging information. This was possible to observe due to the fact that the other speaker began to reveal such nervous movements as tossing and turning as well as moving back and forth. However, the increased level of proxemics contributed not only to the use of the above-mentioned forms of behaviour but also influenced the recipient's vocalic aspects, signalled by the so-called falling intonation and much slower pace of speaking and therefore delivering further information. In other words, when making use of proxemics, the speaker violated the recipient's comfort zone and thus made them accept the unwanted viewpoint or agreement.

When it comes to oculesics, another factor investigated in the target research, maintaining eye-contact was the component closely related to proxemics since it usually concentrated on the same goal, i.e. making the other participant feel uncomfortable. In consequence, 21 subjects (out of 24 participating in the final stage of this research) found this feature much more significant and useful, which was concluded on the basis of the amount of time they maintained this feature in the target conversation. Due to the fact that the intended exchange of information (aimed at reaching a proper consensus) was supposed to take no more than 5 minutes, the author calculated that, on average, each subject maintained eye-contact for 3 minutes 11 seconds. However, there were eleven subjects who maintained eye-contact for almost the whole conversation, i.e. 4 minutes 27 seconds on average (their conversations lasted 4 minutes 48 seconds on average), which means that they found this feature enormously valuable in order to dominate their acts of communication and therefore reach the expected agreement. Constant eye-contact signals self-confidence and listeners are much more willing to accept someone else's viewpoint, even if it is contradictory to their individual views and beliefs. What is more, oculesics allowed the dominant participants to signal various attitudes through the use of eyebrow movement. Therefore, listeners felt often confused and surprised by their partners' reactions and were not keen on continuing the target information exchange. Significant as oculesics was, it was closely related to proxemics, which usually assisted that component.

Kinesics, which is based on various body language movements, was another widely applied aspect of non-verbal communication. The subjects made use of an abundance of various signals in order to inform the reader about their feelings or impressions, or simply to show disapproval or a lack of acceptance. Therefore, shrugging shoulders or drumming fingers were frequently used to disorientate or distract the listener; what is even more, the above-mentioned movements were also used to mislead the other participants. However, it must be stressed that that body language movements were rather naturalised and, thus, movements like scratching neck or head were used to signal numerous intentions, like misunderstanding, uncertainty, confusion, or even boredom. That is why the listener could easily get lost since one needed to 
read the intended meaning skilfully in order to stay in a conversation and avoid getting lost. The speakers also applied head movements to show disapproval or even ignorance. Apart from that, facial expressions were extensively sued to express an array of emotions, such as seriousness, happiness, disagreement, etc.

When it comes to such elements as posture and chronemics, the former one refers to the way the dominant students maintain their body positions, whereas the latter one suggests whether students use breaks or pauses in order to gain time to think about possible responses or reactions, or even think about taking a different course of action to possibly succeed in a conversation. However, the dominant participants maintained the straight position of their bodies, with no slouching, bending or other nervous movements, mainly to show selfconfidence and certainty of what they were doing. As far as chronemics is concerned, no waiting or pausing was made use of. Conversations were based on immediate answers, disallowing the other participants to think about their strategies. In other words, dominance aims at fluent exchange of information and accurate answers, with no time for hesitation.

Finally, vocalics and sound symbols ought to be considered. The research revealed that the majority of the subjects use varied intonation, either raised or lowered, in order to signal emotional states and the ways they feel at particular moments. Furthermore, varied pace and timbre are implemented, which means that the dominant participants use thinner or thicker voice in order to seem more natural. As regards sound symbols, grunting or mumbling, i.e. gapfillers, were barely used in order to maintain communication by the leading members of communicative acts.

\section{Conclusions}

The presented research reveals that non-verbal communication is among the vital aspects of verbal perlocutionary giftedness and seems to be crucial when aiming at dominating a conversation and achieving the target goal, thus forcing the listener to accept even an undesired viewpoint or, simply due to a lack of resources to respond or defend individual suggestions and arguments. This argument leads to the fact that perlocutionarily gifted language users make extensive use of the non-verbal aspects of communication described in the previous section of this paper. As a result, extensive non-verbalism seems to be an indispensable and undisputable aspect of perlocutionary giftedness. The more effective a particular student reveals to be, the more skilfully one uses various aspects of non-verbal communication in order to overwhelm and disorientate the listener. Apart from that, perlocutionarily gifted language users know how to manipulate their resources, when and how to use them, or even modify to distract and confuse the listener in order to succeed and dominate a conversation.

The conducted experiments also suggest that perlocutionary giftedness aims at overwhelming listeners, who seem to get lost and confused when deciphering the speaker's intentions and reading multiple non-verbal aspects of communication. Furthermore, it takes too much time for them to decode numerous signals sent concomitantly, and they easily abandon their own objectives. This suggests that simple communicative acts are highly complex processes and require numerous skills and aspects combined together in order to succeed and dominate communication. However, only careful observers can notice the complexity and 
scope of this phenomenon, which is highly relevant when considering verbal communication and why some members of various acts of communication are better at achieving their goals and forcing other language users to simply give up and accept someone else's point of view or opinion. Therefore, the fact that the non-verbal language generates as much as 55 per cent of the whole impact of communication seems to be greatly supported by tangible evidence.

\section{Summary}

The presented article constitutes an important piece of contribution to the development of the concept of verbal perlocutionary giftedness and its future evolution. The research shows that perlocutionary aptitude goes much beyond its underlying features, such as grammatical and lexical sensitivity, increased willingness to communicate, or skilful manipulation of language resources. Therefore, the concept seems to be enriched by such elements as complex nonverbalism of language communication, mainly through the use of such aspects as kinesics, oculesics, or proxemics. This confirms the fact that communication is endlessly complex and numerous factors have to be considered when approaching the topic of speaking skills and perlocutionary acts and effects, which are indispensable of that particular notion. However, the topic is still to be researched and developed, so further factors influencing verbal perlocutionary giftedness, such as the roles of axiology and multiple intelligences, are going to be described soon. Nevertheless, as each language teacher and researcher approaches and faces the presented topic on a daily basis, often unconsciously, the presented concept seems to be of primary importance for all members of language communities.

\section{References}

Austin, J. L. 1962. How to do things with words. Oxford: Clarendon Press.

Biedroń, A. 2011. Personality factors as predictors of foreign language aptitude. Studies in Second Language Learning and Teaching 1(4): 467-489. Słupsk: Wydawnictwo Naukowe Akademii Pomorskiej w Słupsku.

Brown, D. H. 2000. Teaching by Principles: An Interactive Approach to Language Pedagogy. New York: Pearson Education.

Campbell, P. N. 1973. A rhetorical view of locutionary, illocutionary, and perlocutionary acts. Quarterly Journal of Speech 59: 284-296.

Cap, P. 2010. Text, discourse, function: further ways into pragmatics. In B. Lewandowska-Tomaszczyk (ed.), New Ways to Language, 187-218. Łódź: Łódź University Press.

Carroll, J. B. 1962. The prediction of success in intensive foreign language training. Pittsburgh: University of Pittsburgh Press.

Cohen, T. 1979. Illocutions and perlocutions. Foundations of Language 9: 492-503.

Davis, S. 1979. Perlocutions. Linguistics and Philosophy 3: 225-243.

DeKeyser, R. M. 2007. Practice in a Second Language. Perspectives from Applied Linguistics and Cognitive Psychology. Cambridge: Cambridge University Press.

Dornyei, Z., and P. Skehan. 2003. Individual Differences in Second Language Learning. In C. J. Doughty, and M. H. Long (eds.), The handbook of second language acquisition, 589-630. Oxford: Blackwell.

Ellis, R. 1997. Second Language Acquisition. Oxford: Oxford University Press.

Gaines, R. 1979. Doing by saying: Toward a theory of perlocution. The Quarterly Journal of Speech 65: 207-217.

Hajduk, Z. 2001. Ogólna metodologia nauk. Lublin: Wydawnictwo Katolickiego Uniwersytetu Lubelskiego.

Huang, Y. 2014. Pragmatics. Oxford: Oxford University Press. 
Kalisz, R. 1993. Pragmatyka językowa. Gdańsk: Wydawnictwo Uniwersytetu Gdańskiego.

Krzeszowski, T. P. 1997. Angels and Devils in Hell. Elements of Axiology in Linguistics. Warszawa: Wydawnictwo Energeia.

Leech, G. N. 1983. Principles of Pragmatics. London: Longman.

Levinson, S. C. 1980. Speech act theory: The state of the art. Language Teaching and linguistics: Abstracts, 5-24.

Marcu, D. 2000. Perlocutions: the Achilles' heel of speech act theory. Journal of Pragmatics 32: 1719-1741.

Osika, G. 2001. Teorie aktów mowy. Zeszyty Naukowe Politechniki Śląskiej: Seria Organizacja i Zarządzanie 6(1520): 1-22.

Osika, G. 2008. The communicative acts as action. Lingua ac Communitas. Journal of philosophy, language and communication 18: 35-44.

Pieter, J. 1967. Ogólna metodologia pracy naukowej. Zakład Narodowy im. Ossolińskich, Warszawa: Wydawnictwo Polskiej Akademii Nauk.

Plisiecka-Witczak, I. 2013. From Speech Acts to Speech Actions. Łódź: Łódź University Press.

Post, M. 1999a. Analysing the unanalyzable: perlocutionary acts and perlocutionary effects. In A. Ciuk (ed.), Prof. Dr Gerhard Nickel's 70th Birthday. A Festschrift, 27-38. Opole: Instytut Filologii Angielskiej, Uniwersytet Opolski.

Post, M. 1999b. Perlocutionary expressions. Their nature and acquisition. In M. Wysocka (ed.), On Language Theory and Practice vol. II. Tom jubileuszowy dedykowany Profesorowi Januszowi Arabskiemu, 101-109. Katowice: Wydawnictwo Uniwersytetu Śląskiego.

Post, M. 1999c. Towards a Framework for the Study of Perlocutionary Acts. Linguistica Silesiana 20: 19-30.

Post, M. 2001. Efekty i akty perlokucyjne. In W. Kubiński, and D. Stanulewicz (eds.), Językoznawstwo kognitywne II, 135-147. Gdańsk: Wydawnictwo Uniwersytetu Gdańskiego.

Post, M. 2011. Od aksjologii lingwistycznej do lingwistyki aksjologicznej [From linguistic axiology to axiological linguistics]. In Z. Wąsik, and M. Post (eds.). 2012. Papers and Studies in Axiological Linguistics 7: 35-46. Wrocław: Wydawnictwo Wyższej Szkoły Filologicznej we Wrocławiu.

Post, M. 2013. Speech Acts and Speech Genres. An Axiological Linguistics Perspective. Wrocław: Wydawnictwo Wyższej Szkoły Filologicznej we Wrocławiu.

Ross J. R. 1970. On declarative sentences. In R. A. Jacobs, and P. S. Rosenbaum (eds.), 1970: Readings in English Transformational Grammar, 222-272. Waltham MA: Ginn and Company.

Sadock, J. M. 1974. Toward a Linguistic Theory of Speech Acts. New York: Academic Press.

Safar, A., and Kormos, J. 2008. Revisiting problems with foreign language aptitude. International Review of Applied Linguistics in Language Teaching 46(2): 113-136.

Searle, J. 1962. Meaning and Speech Acts. Philosophical Review 71(4): 423-432.

Searle, J. 1968. Austin on Locutionary and Illocutionary Acts. Philosophical Review 77(4): 405-424

Searle, J. 1969. Speech Acts. Cambridge: Cambridge University Press.

Searle, J. 1975. A Taxonomy of Illocutionary Acts. In K. Gunderson (ed.), Language, Mind and Knowledge. Minnesota Studies in the Philosophy of Science VII, 344-369. Minneapolis: University of Minnesota Press.

Searle, J. 1976. A classification of illocutionary acts. Language in Society 5(1): 1-23.

Searle, J. R., and D. Vanderveken. 1985. Foundations of Illocutionary Logic. Cambridge: Cambridge University Press.

Świątek, A. 2016. The role of individual differences in the verbal aptitude of advanced learners of English to perform perlocutionary acts. Wrocław: Wydawnictwo Wyższej Szkoły Filologicznej we Wrocławiu.

Vanderveken, D. 2002. Searle on meaning and action. In G. Grewendorf, and G. Meggle (eds.), Speech acts, Mind and Social Reality Discussions with Searle, Studies in Linguistics and Philosophy, 141-161. Dordrecht: Kluwer.

Williams, C. 2007. Research methods. Journal of Business and Economic Research, Colorado: Grand Canyon University Press 5(3): 65-72.

Zdunkiewicz, D. 1993. Akty mowy. In J. Bartmiński (ed.), Encyklopedia kultury polskiej XX wieku. Tom 2: Wspótczesny język polski, 259-270. Wrocław: Wiedza o kulturze. 